\title{
組合せ荷重を受けるアンカーボルトと周辺コンクリートの 力学的挙動に関する実験研究
}

\section{EXPELIMENTAL STUDY ON MECHANICAL BEHAVIOR OF ANCHOR BOLTS AND SURROUNDING CONCRETE UNDER COMBINED LOADING}

\author{
白井佑 樹*1, 山田哲*2, 坂田弘安*3, 島田侑子*4, 吉敷祥 一 ${ }^{* 5}$ \\ Yuki SHIRAI, Satoshi YAMADA, Hiroyasu SAKATA, \\ Yuko SHIMADA and Shoichi KISHIKI
}

\begin{abstract}
The purpose of this study is to describe the failure behavior, ultimate strength, yield strength of anchor bolts and the surrounding concrete under combined loads and the effect of reinforcement in the concrete. Monotonic loading tests were conducted for both headed and bonded anchor bolts in ordinary concrete. The ultimate strength when the anchor bolt ruptures or the bond fractures under combined loads are in good correlations with the design recommendation. However, the ultimate strengths when concrete cone failure occurs are in poor correlation with the design recommendation. New equations are proposed for evaluating the ultimate strength under combined loads. Stiffness deterioration occurs when the anchor bolts yield. The yield strength under combined loads is in good correlations with the estimates based on a beam on an elastic foundation theory and the M-N interaction curve.
\end{abstract}

Keywords : Headed Anchor Bolts, Bonded Anchor Bolts, Combined Loading, Ultimate Strength, Yield Strength 頭付きアンカーボルト，接着系アンカーボルト，組合せ荷重，終局耐力，降伏耐力

\section{1. はじめに}

アンカーボルトは，頭付きアンカーボルト，接着系アンカーボル トに代表されるように，鉄骨造柱脚のコンクリート基礎への接合や 既存鉄筋コンクリート造建築物の耐震補強における新設耐震要素の 接合に用いられている。これらアンカーボルトに関して多くの引張 載荷実験 ${ }^{1), 2)}$, せん断載荷実験 ${ }^{3), 4}$, そして数值解析 ${ }^{5)}$ が国内外で広 く行われてきた。これらの成果に基づき，各種合成構造設計指針・ 同解説 $\left(\right.$ 以後, 指針 $\left.{ }^{6}\right)$ ) において終局強度算定式が提案されている。

既往研究の多くは，実験によりアンカーボルトに引張力もしくは せん断力のみが作用する条件を扱っており, 引張力とせん断力が複 合的に作用する組合せ荷重下での実験は少ない7),8),9)。またこれらの 実験の多くはアンカーボルトの破断に着目したものであり ${ }^{77,8)}$, コン クリートのコーン状破壊に言及したものは少ない 9)。過去の地震で も見られた被害であるが，東北地方太平洋沖地震では写真 1 のよう な，アンカーボルトに引張力とせん断力が作用することによって引 き起こされたと考えられる破断やコンクリートのコーン状破壊が報

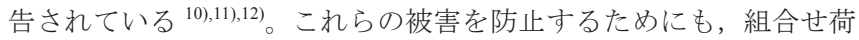
重下でのアンカーボルトとその周辺コンクリートの破壊性状に関寸 る幅広い検討が必要である。

本論では, アンカーボルトとその周辺コンクリートを取り出した 試験体を製作し，アンカーボルトに対して組合せ荷重を与える実験

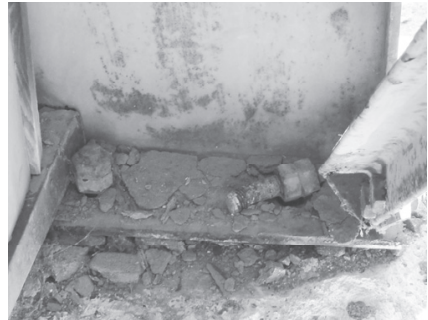

(a) アンカーボルトの破断

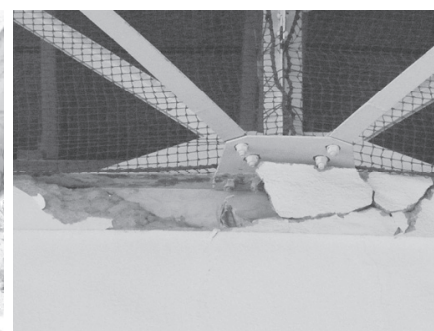

(b) コンクリートの破壊
写真 1 東北地方太平洋沖地震での被害

を行い，組合せ荷重を受けるアンカーボルトとその周辺コンクリー トの終局耐力を評価するとともに, 荷重と変位の関係に基づきコン クリートに埋め込まれたアンカーボルトの降伏耐力を評価する。

\section{2. 実験概要}

\section{1 試験体}

図 1 に試験体形状を示寸。試験体は図 1 に示寸幅をパラメータと した長さ $700 \mathrm{~mm}$, 高さ $400 \mathrm{~mm}$ のコンクリートとそれに埋め込まれ たアンカーボルトからなる。試験体の高さは，一般的な戸建住宅基 礎のせいの半分程度を想定している。アンカーボルトをコンクリー 卜上面中央に配し,有効埋め込み長さ $l_{e}$ は $12 d_{a}$ とした。ここで $d_{a}$ は アンカーボルトの径である。

\footnotetext{
*1 東京工業大学大学院 大学院生 $\cdot$ 修士 (工学) 日本学術振興会特別研究員

*2 東京工業大学 建築物理研究センター 教授・博士 (工学)

*3 東京工業大学大学院 理工学研究科 教授. 工博

*4 千葉大学大学院 工学研究科 准教授・博士 (工学)

*5 東京工業大学 建築物理研究センター 准教授・博士 (工学
}

Grad. Stud., Tokyo Institute of Technology, M. Eng. JSPS Research Fellow

Prof., S.E.R.C., Tokyo Institute of Technology, Dr. Eng. Prof., Graduate School of Science and Eng., Tokyo Institute of Technology, Dr. Eng. Assoc. Prof., Graduate School of Engineering, Chiba Univ., Dr. Eng. Assoc. Prof., S.E.R.C., Tokyo Institute of Technology, Dr. Eng. 
表 1 に試験体一覧を示す。試験体は 24 体である。実験パラメータ は, コンクリート設計基準強度 $F_{c}$, アンカーボルト種類, 加力方向 $\theta$, へりあき距離 $c$, そして配筋の有無である。コンクリート設計基 準強度 $F_{c}$ は $18 \mathrm{~N} / \mathrm{mm}^{2}, 13.5 \mathrm{~N} / \mathrm{mm}^{2}$ を設定した。表 1 に実験時のコン クリートの材料試験結果を示す。なお, 実験時のコンクリート圧縮 強度 $\sigma_{B}$ はそれぞれ， $\sigma_{B}=33 \mathrm{~N} / \mathrm{mm}^{2}, 17 \mathrm{~N} / \mathrm{mm}^{2}$ 程度であった。

アンカーボルトには, 頭付きアンカーボルト（以下， $\mathrm{H}$ ボルト) と接着系アンカーボルト（以下， B ボルト）を設定する。 $\mathrm{H}$ ボルト に SR235（ $\phi 16 ）, \operatorname{SS} 400(\phi 16), \operatorname{SBPR} 1080 / 1230 （ \phi 17 ） を, B$ ボル トにSD345（D16）, SHD685（D16）を用いた。表1にアンカーボル 卜の力学的特性を示す。 $\mathrm{H}$ ボルトの頭部には小径, 及び厚さが, $\phi 16$ に対して径の 1.7 倍, 及び 1.0 倍, $\phi 17$ に対して径の 2.1 倍, 及び 1.6 倍のナットを称じ接合した。B ボルトの先端を 45 度に切断し, 回 転・打撃型の接着系アンカーを用いた。接着剤は有機系である。

加力方向 $\theta$ は, アンカーボルト材軸方向からの傾きと定義し, 0 度，30度，60度を設定した。

へりあき距離 $c$ は試験体幅の半分に対応し, $350 \mathrm{~mm}, 200 \mathrm{~mm}$, 及 び $75 \mathrm{~mm}$ を設定した（以下， $\mathrm{mm}$ を省略）。

アンカーボルト周辺の鉄筋について, 図 2 に配筋図を示す。鉄筋 はコーン状破壊が想定される面を通るように配筋した。配筋は同規 模のアンカーボルトが使用される戸建住宅基礎の配筋と同程度とし, アンカーボルトの直交方向（主筋）に1-D13，材軸方向（せん断補 強筋）にD10@300 を配し，鉄筋には SD295A を用いた。主筋はは しあき端で捨て型枠を兼ねた鋼板に，せん断補強笳は試験体下部の 鋼板に点付け溶接で固定した。

\section{2 実験方法}

図 3 にセットアップ状況の一例と計測状況を示す。試験体をアン カーボルトが垂直になるよう加カフレームに配置し, 試験体下部鋼 板の内側に設置したナットを介してボルトで固定した。アンカーボ ルトは, 加力治具, PC 鋼棒（ $\phi 19 ）$ を介して反力フレームに取り付 けた油圧ジャッキにより加力し，その反力をロードセルにより計測 する。アンカーボルトと加力治具はナットで接合され, アンカーボ ルトに数マイクロの歪度が生じる程度までナットを締めた。PC 鋼棒 の材軸方向の傾きが加力方向 $\theta$ と対応し, コンクリート表面におけ るアンカーボルト図心位置を通る。加力に伴う PC 鋼棒の材軸方向 の傾きの変化は, $\mathrm{PC}$ 鋼棒両端のナット接合は回転拘束が小さく,ま

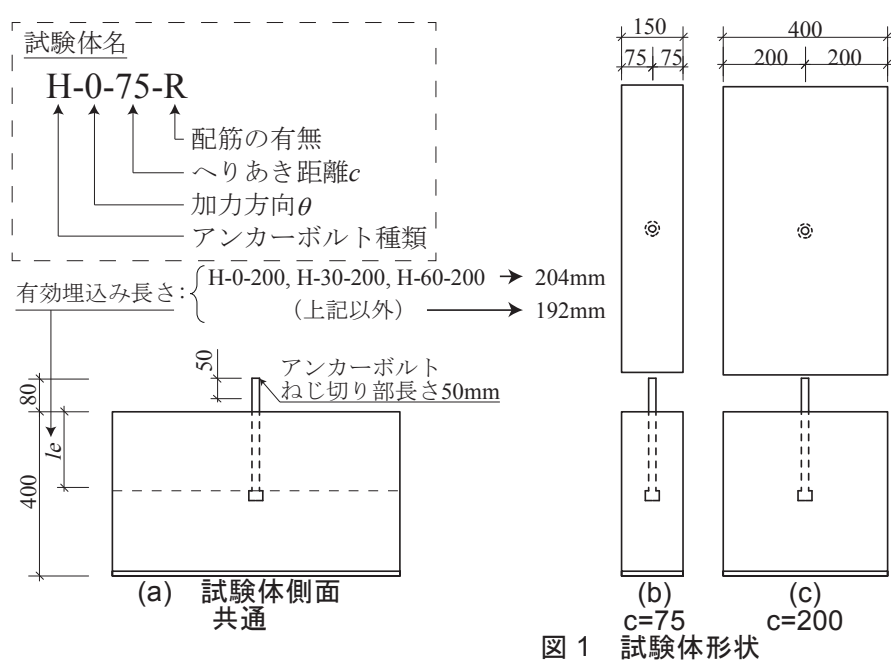

たアンカーボルトの最大変形時においても最大で 2 度程度となり, この影響は少ないと考える。加力は一方向単調載荷とし, 明確な破 壊性状の発現，またはアンカーボルトの完全な引抜きまで行った。

計測項目は, ロードセルによる $\mathrm{PC}$ 鋼棒の軸力 $n_{e}$, コンクリート 表面でのアンカーボルトの鉛直変位 $\delta_{V}$, 水平変位 $\delta_{H}$, 及びアンカー ボルト（H ボルトのみ）と主筋, せん断補強筋の歪度, そしてコン クリートのひび割れ幅である。変位は図 3 に示寸ように, 試験体コ ンクリートに固定された計測治具より，加力治具に設置したターゲ ットの動きを計測し、コンクリートからの相対変位とした。そのた め, コンクリート表面からターゲットまでのアンカーボルトの変形 量を含んでいるが，その值は最大でも $0.1 \mathrm{~mm}$ 程度であり，本論では 無視できると考えた。ひび割れ幅は， $n_{e}$ の $10 \mathrm{kN}$ 毎に計測した。

\section{3. 実験結果}

\section{1 破壊性状の概要}

表 2 に実験での破壊性状の一覧を，写真 1 に破壊状況を示す。破 壊性状として, アンカーボルト破断, 付着破壊, 及びコンクリート のコーン状破壊が観察された。

写真 2(a)にアンカーボルト破断の状況を示す。アンカーボルト破 断はコンクリートから突出したナット下部で生じた。破断は, 加力 方向 $\theta$ が 0 度の H-0-75-R, H-0-350, B-0-350 ではアンカーボルトの ねじ部で, $\theta か ゙ 30$ 度, 60 度の H-30-350, H-60-350, B-30-350, B-60-350 ではアンカーボルトの軸部で見られ，いずれもアンカーボルトのし ぼりを伴う破断であった。せん断力が作用する $\theta$ が30度, 60 度では, アンカーボルトからの支圧によるコンクリートの圧壊，コンクリー ト内部でのアンカーボルトの曲げ変形が見られた。

写真 2(b)に付着破壊の状況を示す。付着破壊は, B ボル卜の加力 方向 $\theta$ が 0 度である B-0-200, B-0-75, B-0-75-R で見られた。アンカ 一ボルトはコンクリートから抜け出る性状を示し, 接着剤とコンク リートの界面で破壞が生じた。コンクリートのひび割れは，コーン 状破壊時とは異なり，コンクリートが分離するような全断面には及 ばず，アンカーボルトを引抜いた後もコンクリートは一体性を保っ ていた。コンクリートのひび割れは，破壊と同時に上面のへりあき 方向と側面のアンカーボルト材軸に沿って生じた。

写真 2(d) (f)にコーン状破壞の状況を示す。コーン状破壊は, 前述 以外の試験体で見られた。またこの破壊では加力方向 $\theta か ゙ 0$ 度のひび

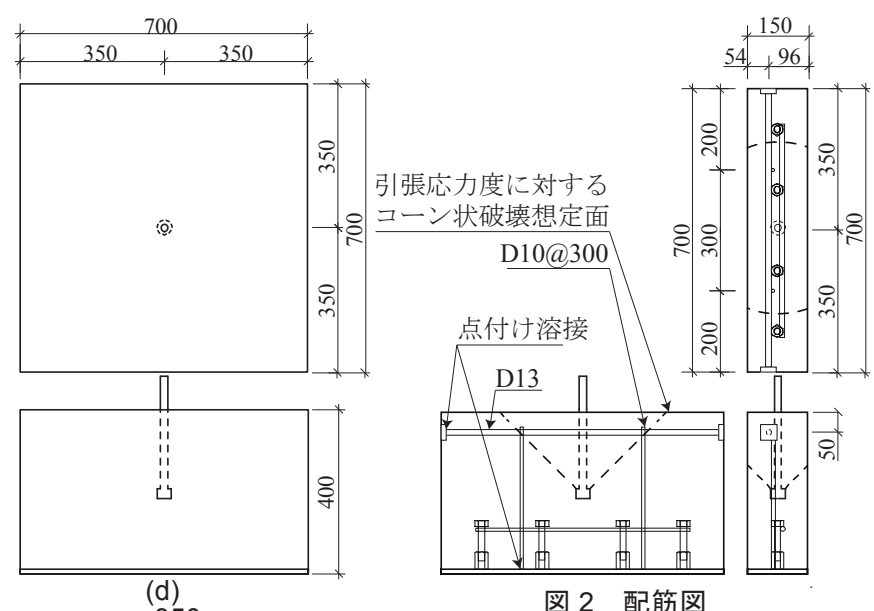

(配筋された試験体) 
表 1 試験体一覧

\begin{tabular}{|c|c|c|c|c|c|c|c|c|c|c|c|}
\hline \multirow{5}{*}{ 試験体 } & \multirow{2}{*}{\multicolumn{5}{|c|}{ 実験パラメータ }} & \multicolumn{6}{|c|}{ 使用材料の力学的特性 } \\
\hline & & & & & & \multicolumn{3}{|c|}{ アンカーボルト ${ }^{2}$} & \multicolumn{3}{|c|}{\begin{tabular}{|l} 
コンクリート \\
\end{tabular}} \\
\hline & \multirow{2}{*}{\begin{tabular}{||c|} 
コンクリート \\
設計基準強度 \\
$F_{c}$ \\
\end{tabular}} & \multirow{2}{*}{$\begin{array}{l}\text { アンカー } \\
\text { ボルト種類 }\end{array}$} & 加力方向 & \multirow{2}{*}{$\begin{array}{c}\text { へりあき } \\
\text { 距離 }\end{array}$} & \multirow{2}{*}{$\begin{array}{c}\text { 配筋の } \\
\text { 有無 }\end{array}$} & 鋼種 & 降伏強さ & 引張強さ & 圧縮強度 & $\begin{array}{c}\text { ヤング係 } \\
\text { 数 }\end{array}$ & 引張強度 \\
\hline & & & $\theta$ & & & - & $\sigma_{y}$ & $\sigma_{u}$ & $\sigma_{B}$ & $E_{c}\left(\times 10^{4}\right)$ & $\sigma_{T}$ \\
\hline & $\mathrm{N} / \mathrm{mm}^{2}$ & - & 度 & $\mathrm{mm}$ & - & - & \multicolumn{2}{|c|}{$\mathrm{N} / \mathrm{mm}^{2}$} & \multicolumn{3}{|c|}{$\mathrm{N} / \mathrm{mm}^{2}$} \\
\hline "H-0-75-R & \multirow{12}{*}{18} & $\mathrm{H}$ & \multirow[b]{2}{*}{0} & \multirow{6}{*}{75} & \multirow{6}{*}{ 配筋有 } & SS400 & 336 & $4 \quad 466$ & 33.7 & 2.55 & 3.1 \\
\hline B-0-75-R & & $\mathrm{B}$ & & & & SD345 & 397 & 547 & 33.7 & 2.55 & 3.1 \\
\hline H-30-75-R & & $\mathrm{H}$ & \multirow[b]{2}{*}{30} & & & SS400 & 336 & 466 & 32.1 & 2.55 & 2.9 \\
\hline B-30-75-R & & $\mathrm{B}$ & & & & SD345 & 397 & 547 & 32.1 & 2.55 & 2.9 \\
\hline $\mathrm{H}-60-75-\mathrm{R}$ & & $\mathrm{H}$ & \multirow{2}{*}{60} & & & SS400 & 336 & 466 & 31.5 & 2.55 & 2.9 \\
\hline B-60-75-R & & $\mathrm{B}$ & & & & SD345 & 397 & 547 & 31.6 & 2.55 & 2.9 \\
\hline H- $0-350$ & & $\mathrm{H}$ & \multirow[b]{2}{*}{0} & \multirow{6}{*}{350} & \multirow{18}{*}{ 配筋無 } & SS400 & 336 & 466 & 33.1 & 2.55 & 3.0 \\
\hline B-0-350 & & $\mathrm{B}$ & & & & SD345 & 397 & 547 & 33.2 & 2.55 & 3.0 \\
\hline H-30-350 & & $\mathrm{H}$ & \multirow[b]{2}{*}{30} & & & SS400 & 336 & 466 & 32.1 & 2.55 & 2.9 \\
\hline B-30-350 & & $\mathrm{B}$ & & & & SD345 & 397 & 547 & 32.2 & 2.55 & 2.9 \\
\hline $\mathrm{H}-60-350$ & & $\mathrm{H}$ & \multirow[b]{2}{*}{60} & & & SS400 & 336 & 466 & 31.6 & 2.55 & 2.9 \\
\hline B-60-350 & & $\mathrm{B}$ & & & & SD345 & 397 & 547 & 31.6 & 2.55 & 2.9 \\
\hline $\mathrm{H}-0-200$ & \multirow{12}{*}{13.5} & $\mathrm{H}$ & \multirow[b]{2}{*}{0} & \multirow{6}{*}{200} & & \begin{tabular}{||l} 
SBPR1080/1230 \\
\end{tabular} & 1154 & 1251 & 16.6 & 1.91 & 1.6 \\
\hline B-0-200 & & $\mathrm{B}$ & & & & SHD685 & 760 & 955 & 16.5 & 1.89 & 1.5 \\
\hline $\mathrm{H}-30-200$ & & $\mathrm{H}$ & \multirow{2}{*}{30} & & & SBPR1080/1230 & 1154 & 1251 & 17.2 & 1.97 & 1.8 \\
\hline B-30-200 & & $\mathrm{B}$ & & & & SHD685 & 760 & 955 & 16.8 & 1.93 & 1.6 \\
\hline H-60-200 & & $\mathrm{H}$ & \multirow[b]{2}{*}{60} & & & SBPR1080/1230 & 1154 & 1251 & 17.5 & 2.00 & 1.9 \\
\hline B-60-200 & & $\mathrm{B}$ & & & & SHD685 & 760 & 955 & 17.5 & 2.00 & 1.9 \\
\hline H-0-75 & & $\mathrm{H}$ & \multirow{4}{*}{30} & \multirow{6}{*}{75} & & SR235 & 320 & 447 & 16.4 & 1.88 & 1.5 \\
\hline B-0-75 & & B & & & & SD345 & 385 & 568 & 16.4 & 1.88 & 1.5 \\
\hline $\mathrm{H}-30-75$ & & $\mathrm{H}$ & & & & SR235 & 320 & 447 & 16.6 & 1.91 & 1.6 \\
\hline B-30-75 & & B & & & & SD345 & 385 & 568 & 16.7 & 1.92 & 1.6 \\
\hline H-60-75 & & $\mathrm{H}$ & & & & SR235 & 320 & 447 & 17.4 & 1.99 & 1.8 \\
\hline B-60-75 & & B & 60 & & & SD345 & 385 & 568 & 17.4 & 1.99 & 1.8 \\
\hline
\end{tabular}

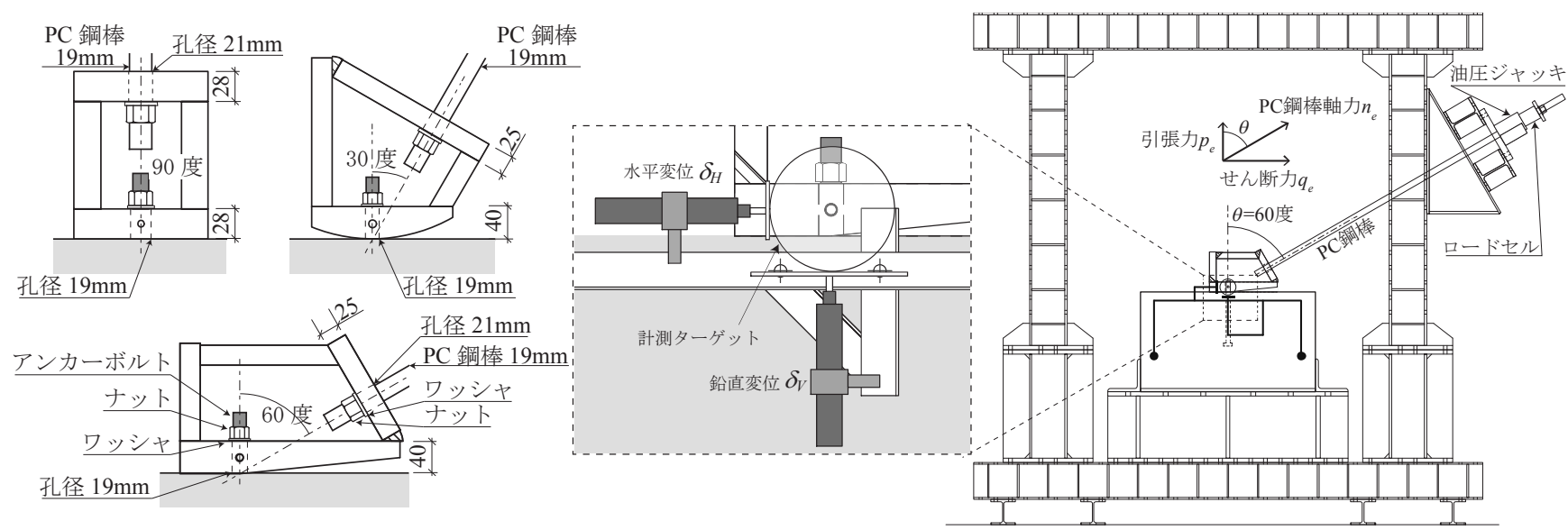

図 3 加力治取付け状況, 及びセットアップ状況の一例（ $\theta=60$ 度）と計測状況

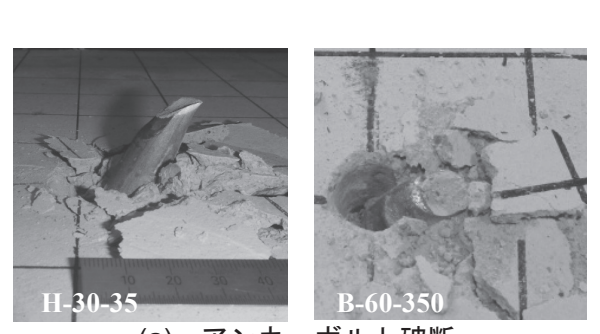

(a) アンカーボルト破断

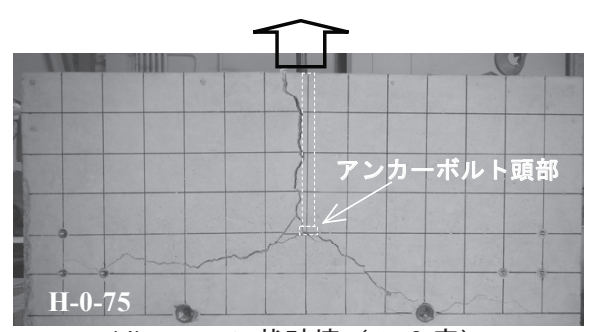

(d) コーン状破壊（ $\theta=0$ 度）

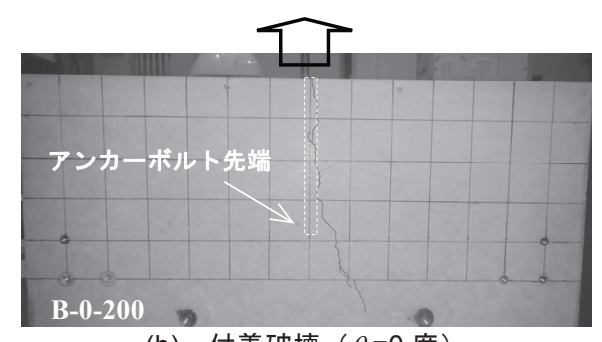

(b) 付着破壊（ $\theta=0$ 度）

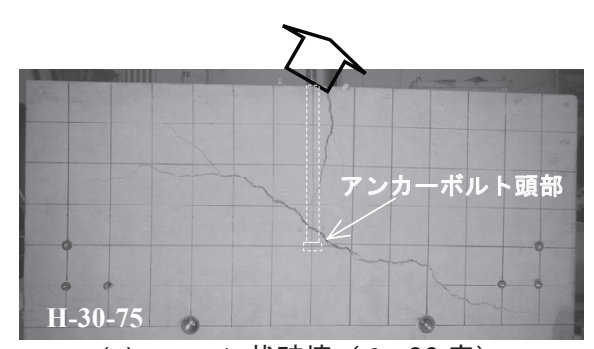

(e) コーン状破壊（ $\theta=30$ 度）

写真 2 破壊状況（mesh@50mm）

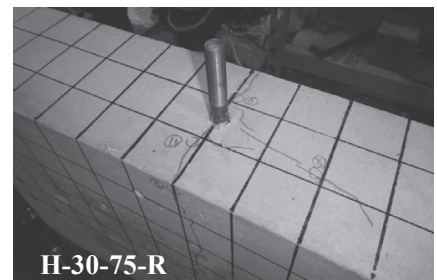

(c) コーン状破壊 上面

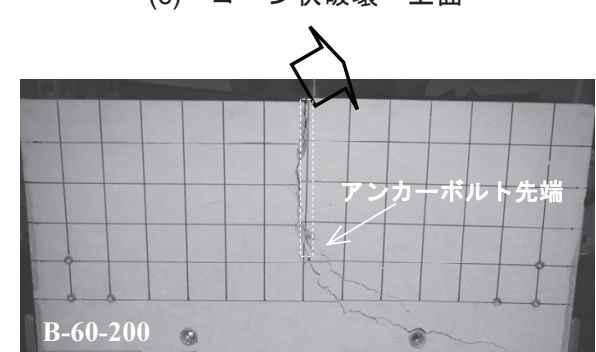

(f) コーン状破壊（ $\theta=60$ 度） 
割れは，破壊と同時にコンクリート上面のへりあき方向と，側面で はアンカーボルト材軸方向, 及びアンカーボルトの頭部から加力直 交方向の左右に生じた。 $\theta$ が30度，60度では，へりあき距離 $c$ が 75 と小さいと, 配筋の有無に関わらず破壊前で最大 $0.2 \mathrm{~mm}$ のひび割れ がコンクリート上面に生じた。 $c$ が 200 の試験体では, 破壊前のひ び割れは確認されなかった。主要なひび割れは破壊と同時に現れ, コンクリート上面のへりあき方向と, 側面ではアンカーボルト材軸 方向, 及びアンカーボルトの頭部または先端を中心に加力直交方向 に沿って生じた。また, 配筋された試験体のコンクリート上面の加 力方向では直線状の割裂ひび割れが見られた（写真 $2(\mathrm{c})$ )。

表 2 に最大ひび割れ幅を示す。最大ひび割れ幅は, 終局耐力後に 全試験体上面のアンカーボルト周辺で観察された。ただし, 配筋無 しでコーン状破壊に至った試験体は, 幅 $10 \mathrm{~mm}$ 以上のひび割れやコ ンクリート片の分離が生じたため, 計測不能と示した。最大ひび割 れ幅は配筋の有無によって異なり, 本実験の範囲においては, 配筋
された試験体の最大ひび割れ幅は $1.0 \mathrm{~mm}$ 程度であった。後述する鉄 筋歪度において, 破壊と同時に鉄筋歪度の増大が確認でき, ひび割 れ幅の進展抑制に鉄筋が作用していることがわかる。

\section{2 終局耐力}

表 2 に試験体の終局耐力の一覧を示す。終局耐力は破壊までの最 大荷重とした。終局耐力時のアンカーボルト材軸方向の引張力 max $p_{e}$ と材軸垂直方向のせん断力 $\max _{e} q_{e}$ は, $\mathrm{PC}$ 鋼棒の軸力 max $_{e} n_{e}$ を加力方向 $\theta$ に応じて分解して得た。

図 4(a)に全試験体の加力軸方向における終局耐力 max $_{e} n_{e}$ を示す。ア ンカーボルト破断に至った試験体の $\max _{e} n_{e}$ は加力方向 $\theta$ に関わらず同 程度となった。一方，コーン状破壊に至った試験体では， $\theta$ が 0 度 で最も $\max _{e} n_{e}$ が大きく, $\theta$ が30度, 60 度で小さくなる傾向が見られた。

図 4(b) に終局耐力時の引張力 max $_{e}$ とせん断力 $\max _{e} q_{e}$ を示す。加力方 向 $\theta$ によって, $\max _{e}$ と $\max _{e} q_{e}$ が異なる值で終局状態に至っており, 組 合せ荷重の影響が確認できる。

表 2 実験結果と指針式 $\left.{ }^{6}\right)$ に基づく計算値

\begin{tabular}{|c|c|c|c|c|c|c|c|c|c|c|c|}
\hline \multirow{5}{*}{ 試験体 } & \multicolumn{5}{|c|}{ 実験結果 } & \multicolumn{6}{|c|}{ 計算值 } \\
\hline & \multirow{3}{*}{ 破壊性状 } & \multirow{3}{*}{$\begin{array}{c}\text { 最大 } \\
\text { ひび割れ幅 }\end{array}$} & \multicolumn{3}{|c|}{ 終局耐力 } & \multicolumn{3}{|c|}{ 引張力を受ける時 } & \multicolumn{3}{|c|}{ "せん断力を受ける時 } \\
\hline & & & $\begin{array}{l}\mathrm{PC} \text { 鋼棒 } \\
\text { 軸力 }\end{array}$ & 引張力 & せん断力 & $\begin{array}{c}\text { アンカー } \\
\text { 破断 }\end{array}$ & $\begin{array}{l}\text { コーン状 } \\
\text { 破壊 }\end{array}$ & 付着破壊 & $\begin{array}{c}\text { アンカー } \\
\text { 破断 }\end{array}$ & 支压破壊 & $\begin{array}{l}\text { コーン状 } \\
\text { 破壊 }\end{array}$ \\
\hline & & & $\max n_{e}$ & $\max p_{e}$ & $\max q_{e}$ & $p_{a 1}$ & $p_{a 2}$ & $p_{a 3}$ & $q_{a 1}$ & $q_{a 2}$ & $q_{a 3}$ \\
\hline & - & $\mathrm{mm}$ & \multicolumn{3}{|c|}{$\mathrm{kN}$} & \multicolumn{3}{|c|}{$\mathrm{kN}$} & \multicolumn{3}{|c|}{$\mathrm{kN}$} \\
\hline H-0-75-R & "アンカー破断(ねじ部) & 0.2 & $\overline{78}$ & 78 & $-\overline{-}$ & $\overline{73}$ & 107 & - & & & \\
\hline $\mathrm{B}-0-75-\mathrm{R}$ & 付着破壊 & 0.7 & 70 & 70 & - & 86 & 104 & 55 & & & \\
\hline H-30-75-R & コーン状破壊 & 0.7 & 37 & 32 & 19 & 94 & 105 & - & 54 & 71 & 91 \\
\hline B-30-75-R & コーン状破壊 & 0.9 & 48 & 41 & 24 & 109 & 103 & 54 & 63 & 71 & 91 \\
\hline H-60-75-R & コーン状破壊 & 0.8 & 36 & 18 & 31 & 94 & 104 & - & 54 & 70 & 91 \\
\hline B-60-75-R & コーン状破壊 & 1.0 & 50 & 25 & 44 & 109 & 120 & 53 & 63 & 70 & 91 \\
\hline $\mathrm{H}-0-350$ & アンカー破断(ねじ部) & 0.1 & 77 & 77 & - & 73 & 236 & - & & & \\
\hline B- $0-350$ & アンカー破断(ねじ部) & 0.2 & 96 & 96 & - & 86 & 226 & 102 & & & \\
\hline $\mathrm{H}-30-350$ & アンカー破断(軸部) & 0.3 & 91 & 79 & 46 & 94 & 232 & - & 54 & 71 & 338 \\
\hline B-30-350 & アンカー破断(軸部) & 0.2 & 99 & 86 & 50 & 109 & 221 & 100 & 63 & 71 & 338 \\
\hline $\mathrm{H}-60-350$ & アンカー破断(軸部) & 0.1 & 77 & 38 & 66 & 94 & 230 & - & 54 & 70 & 335 \\
\hline $\mathrm{B}-60-350$ & アンカー破断(軸部) & 0.2 & 88 & 44 & 76 & 109 & 219 & 99 & 63 & 70 & 335 \\
\hline $\mathrm{H}-0-200$ & コーン状破壊 & (計測不能) & 115 & 115 & - & 284 & 186 & - & & & \\
\hline B-0-200 & 付着破壊 & 3.0 & 86 & 86 & - & 150 & 158 & 71 & & & \\
\hline $\mathrm{H}-30-200$ & コーン状破壊 & (計測不能) & 90 & 78 & 45 & 284 & 190 & - & 164 & 66 & 170 \\
\hline B-30-200 & コーン状破壊 & (計測不能) & 56 & 49 & 28 & 190 & 159 & 72 & 110 & 45 & 168 \\
\hline H-60-200 & コーン状破壊 & (計測不能) & 60 & 30 & 52 & 284 & 191 & - & 164 & 67 & 171 \\
\hline B-60-200 & コーン状破壊 & (計測不能) & 66 & 33 & 57 & 190 & 163 & 73 & 110 & 47 & 171 \\
\hline H-0-75 & コーン状破壊 & (計測不能) & 52 & 52 & - & 70 & 75 & - & & & \\
\hline B-0-75 & 付着破噮 & 5.0 & 43 & 43 & - & 89 & 73 & 38 & & & \\
\hline H-30-75 & コーン状破壊 & (計測不能) & 32 & 28 & 16 & 90 & 75 & - & 52 & 44 & 66 \\
\hline B-30-75 & コーン状破壊 & (計測不能) & 33 & 29 & 16 & 113 & 74 & 39 & 65 & 44 & 66 \\
\hline H-60-75 & コーン状破壊 & (計測不能) & 33 & 16 & 28 & 90 & 77 & - & 52 & 46 & 67 \\
\hline B-60-75 & コーン状破壊 & (計測不能) & 42 & 21 & 36 & 113 & 75 & 39 & 65 & 46 & 67 \\
\hline
\end{tabular}

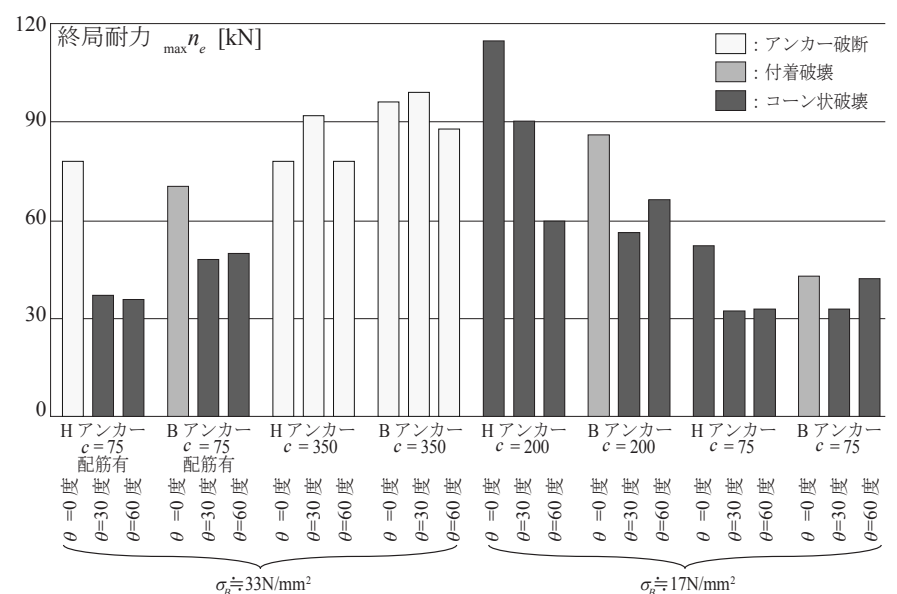

(a) 加力軸方向 max $_{e} n_{e}$

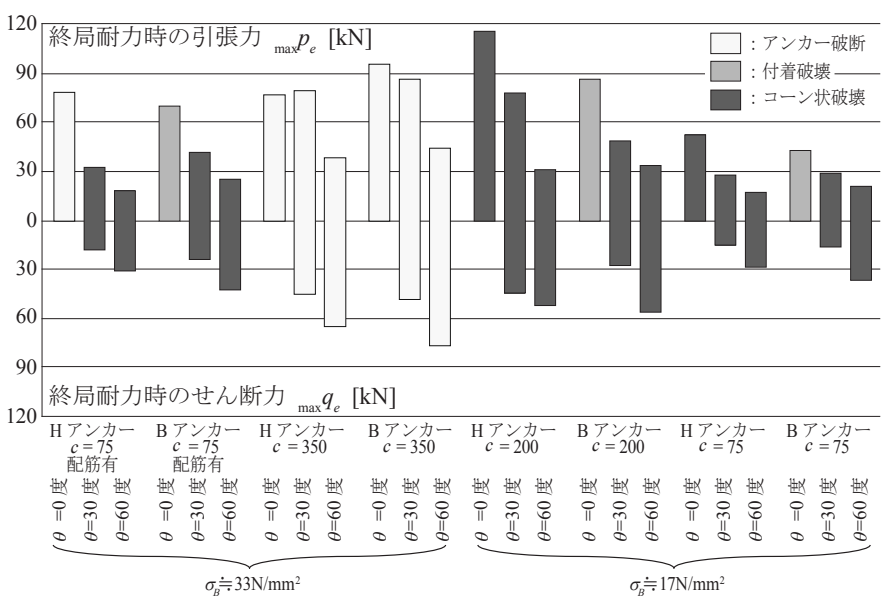

(b) 引張力 $\max _{\operatorname{me}} p_{e}$ とせん断力 $\max _{\mathrm{e}} q_{e}$

図 4 終局耐力 


\section{3 歪度性状}

図 5 に H ボルトの歪ゲージ貼付位置を示す。なお, 歪ゲージはべ ース部に保護養生テープを薄く貼付するのみとし, アンカーボルト の溝切り加工などは行っていない。歪ゲージはアンカーボルト 1 本 につき, コンクリート表面から $2 d_{a}, 4 d_{a}, 10 d_{a}$ の位置に, せん断力 方向に対し表裏に計 6 枚を貼付した。ここで $d_{a}$ はアンカーボルトの 直径である。同一断面表裏の歪度 $\varepsilon^{+}, \varepsilon^{-}$から, 引張歪度 $\varepsilon^{N}$ は式(1), 曲げ歪度 $\varepsilon^{\mathrm{M}}$ は式(2)を用いて算出した。

$$
\begin{aligned}
& \varepsilon^{\mathrm{N}}=\left(\varepsilon^{+}+\varepsilon^{-}\right) / 2 \\
& \varepsilon^{\mathrm{M}}=-\left(\varepsilon^{+}-\varepsilon^{-}\right) / 2
\end{aligned}
$$

図 5 に H ボルトの歪度性状を, へりあき距離 $c$ が 200 の試験体に おける $\mathrm{PC}$ 鋼棒の軸力 $n_{e}$ と引張歪度 $\varepsilon^{\mathrm{N}}$, 曲壮歪度 $\varepsilon^{\mathrm{M}}$ との関係で歪ゲ ージ位置と併せて示す。ここに示すのは全て弾性範囲である。 $\theta$ が 0 度の $\varepsilon^{\mathrm{N}}$ は $n_{e}$ と対応し, 深さ方向で一様に分布しており, $\varepsilon^{\mathrm{M}}$ は微小で あった。 $\theta$ が 30 度, 60 度の $\varepsilon^{\mathrm{N}}$ は $\theta$ が 0 度と同様で, 深さ方向で一様 に分布し, 引張力 $p_{e}$ と対応していた。これより引張力に対しては, せん断力が同時に作用する組合せ荷重下においても軸部で一様な引 張応力度が生じ, アンカーボルト頭部の支圧で抵抗していることが わかった。一方, $\varepsilon^{\mathrm{M}}$ についてはせん断力 $q_{e}$ が大きく, コンクリート 表面に近い, 浅い位置で大きくなる傾向がある。これよりせん断力 に対しては, 浅い位置でアンカーボルトの曲げにより抵抗していた と考える。この傾向は $c$ が 200 の試験体以外でも同様に確認できた。

アンカーボルトの曲げ変形を周辺コンクリートが拘束するため, 曲げ歪度性状は周辺コンクリートの影響を受ける。図 6(a) に H ボル トの曲げ歪度 $\varepsilon^{\mathrm{M}}$ に対するへりあき距離 $c$ の影響を,$c$ が 200 の H-60-200 と 75 の H-60-75 において, $\mathrm{PC}$ 鋼棒の軸力 $n_{e}$ と $\varepsilon^{\mathrm{M}}$ の関係で 示寸。図 6(a)より, へりあき距離 $c$ はアンカーボルトの曲げ歪度性 状に影響をほとんど与えていない。図 6(b)に $\mathrm{H}$ ボルトの曲げ歪度 $\varepsilon^{\mathrm{M}}$ に対する配筋の影響を, 配筋された H-60-75-R と無筋の H-60-350 に おいて, $\mathrm{PC}$ 鋼棒の軸力 $n_{e}$ と $\mathcal{E}^{\mathrm{M}}$ の関係で示す。ここで, これら 2 体 の $c$ は異なるが，前述のようにその影響は少ないと考える。図 6(b) よりコンクリート表面から $2 d_{a}, 4 d_{a}$ の $\mathcal{E}^{\mathrm{M}}$ は, 無筋の試験体と比較し て, 配筋された試験体では $1 / 3$ 程度に小さくなっていた。配筋の有 無により，アンカーボルトの曲げ性状が変化したと考える。

図 7,8 に主筋, 及びせん断補強筋の歪ゲージ貼付位置を示す。主 筋の歪度性状について, 図 7 に B-60-75-R の PC 鋼棒の軸力 $n_{e}$ と主 筋の歪度の関係を示す。終局耐力 $\max _{e}$ までの鋼板近傍の歪度は $100 \mu$ 未満と微小であり，はしあきの鋼板による実験への影響は無視でき る。コンクリート破壊面を貫通しているアンカーボルト近傍の主筋 の歪度は $n_{e}$ の増大に伴い段階的に増大し, この時にコンクリートに ひび割れ等の損傷が生じていたと考えられる。 $n_{e}$ が $40 \mathrm{kN}$ の時に歪 度は $156 \mu$ であり, コンクリート上面のアンカーボルト近傍のひび割 れ幅は $0.1 \mathrm{~mm}$ であった。その後歪度は ${ }_{\text {max }} n_{e}$ の直前で $490 \mu$ にまで増 大し, この直後の破壊と同時に大きく進展した。

せん断補強筋の歪度性状について, 図 8 に H-30-75-R の PC 鋼棒 の軸力 $n_{e}$ とせん断補強筋の歪度の関係を示す。せん断補強筋の歪度 は終局耐力 $\max _{e} n_{\text {ま }}$ で最大でも $100 \mu$ 未満であり, この後の破壊でも 大きく変化しなかった。アンカーボルト破断した H-0-75-R を除く試 験体についても同様であった。以上より主筋に比べせん断補強筋は, コンクリートのコーン状破壊時も応力負担が少ないことがわかった。

\section{4. 終局耐力評価}

実験で観察された各破壊性状の終局耐力を，指針 ${ }^{6}$ に基づいて評 価する。表 2 に指針式 ${ }^{6}$ の考え方を基に材料強度を用いて算出した 終局時の計算值 $p_{a 1} \sim p_{a 3}, \quad q_{a 1} \sim q_{a 3}$ を示す。アンカーボルト破断の計算 では, 引張力方向には引張強さ $\sigma_{u}$ を, せん断力方向には von Mises の降伏条件を破断時に拡張し， $\sigma_{u}$ に $1 / \sqrt{ } 3$ を乗じた值を用いた。有 効断面積は実験での破断位置に対応させた。コーン状破壊と付着破 壊の計算值では, へりあき距離による低減係数を与え, 安全係数は

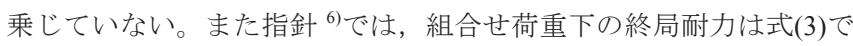
表している。

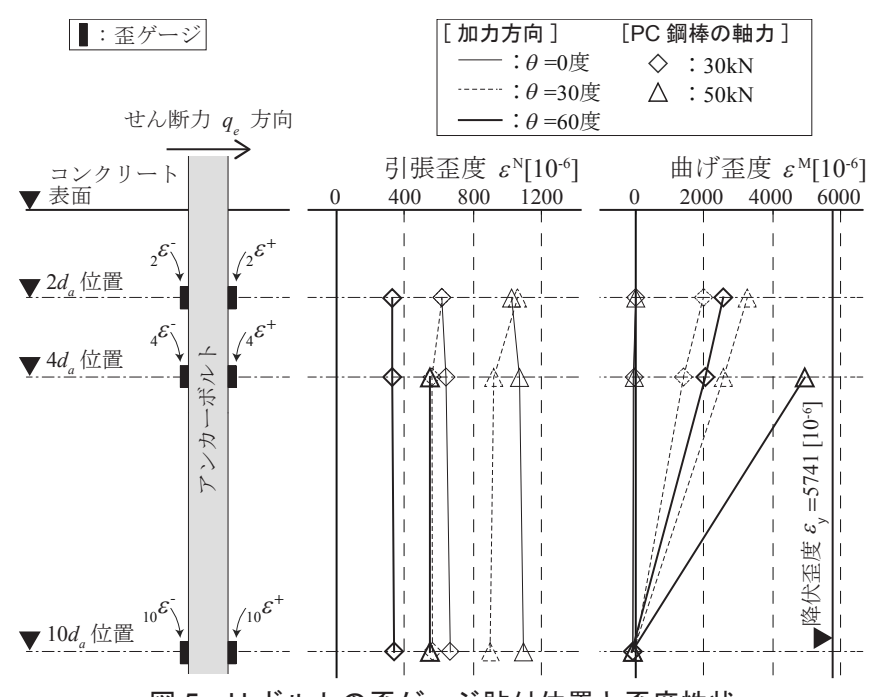

図 5 H ボルトの歪ゲージ貼付位置と歪度性状

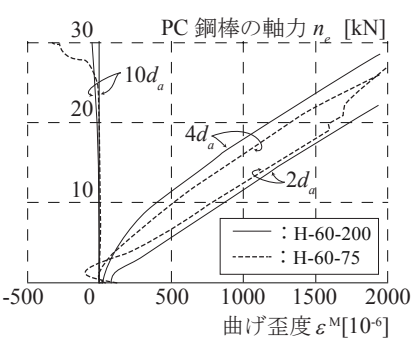

(a) へりあき $C$

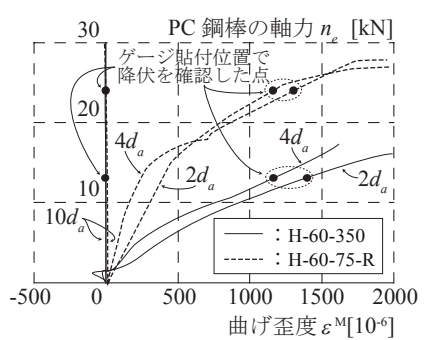

(b) 配筋
図 6 H ボルトの歪度性状に対する周辺コンクリートの影響
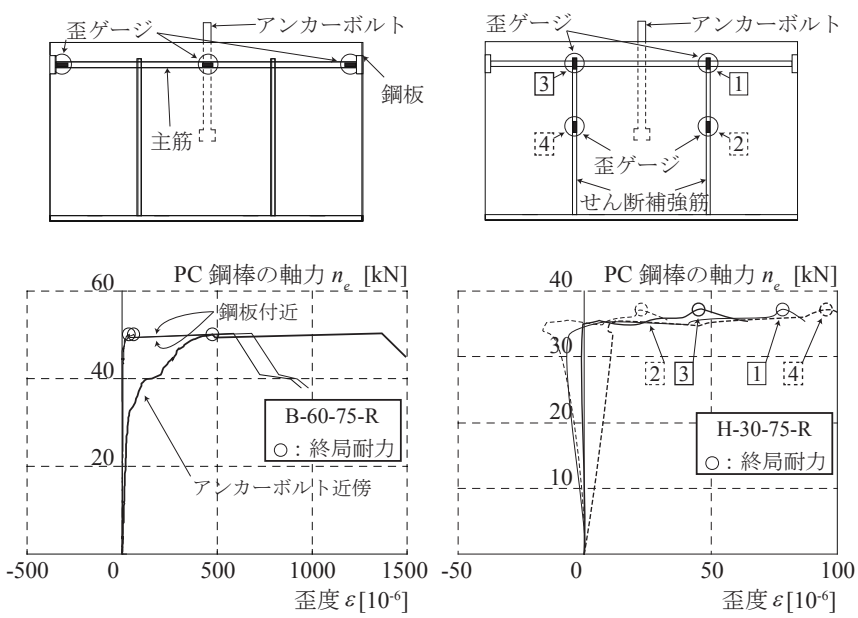

図 7 主筋歪ゲージ貼付位置と 歪度性状（B-60-75-R）
図 8 せ断補強筋歪ゲージ貼 付位置と歪度性状 (H-30-75-R) 


$$
\left({ }_{\max } p_{e} / p_{a}\right)^{2}+\left({ }_{\max } q_{e} / q_{a}\right)^{2}=(1.0)^{2}
$$

終局耐力の評価は, 縦軸を実験結果である終局耐力時の引張力 ${ }_{\max } p_{e}$ を計算值の最小值 $p_{a}=\min \left(p_{a 1}, p_{a 2}, p_{a 3}\right)$ で除した值, 横軸を同様に, せん断力 $\max _{2} q_{e}$ を $q_{a}=\min \left(q_{a 1}, q_{a 2}, q_{a 3}\right)$ で除した值とした, 引張力とせ ん断力の実験值の計算值に対する比の相関図を用いて行う。図 9, 図 12 , 及び図 13 に各試験体の評価結果を○×で示し, ○は計算值 の最小で予測される破壊モードが実験の破壊性状と一致した試験体, ×は不一致の試験体である。

\section{1 アンカーボルト破断耐カ}

図 9 にアンカーボルト破断に至った試験体の評価結果を示す。加 力方向 $\theta$ が 0 度の試験体の終局耐力は計算值と対応しており, 予測 された破壊モードとも一致した。一方, 組合せ荷重を受ける $\theta$ が 30 度, 60度の試験体の終局耐力は, 計算值を 1.2 1.3 倍上回る安全側 の評価となり, B ボルトの試験体では破壊モードが不一致となった。

組合せ荷重を受ける試験体のアンカーボルト破断耐力を過小に評 価した要因を, アンカーボルトの変形状態に基づいて検討する。

図 9 より, 加力方向 $\theta$ が30度の終局耐力時の $\mathrm{PC}$ 鋼棒軸力 $\max _{e} n_{e}$ は 計算值を1.2倍上回っていた。一方で表2より, $\max n_{e}$ と引張力を受け る時の破断耐力 $p_{a l}$ は近い值になっている。これは, 加力方向 $\theta$ と破 断面におけるアンカーボルトの材軸の傾き $\phi$ が一致したことによる と考える。

終局耐力時のせん断力 $\max _{e} q_{e}$ によりアンカーボルトのある断面で 塑性ヒンジが形成され, 水平変位がその塑性ヒンジの回転により生 じると仮定する。図 10(a)に, 塑性ヒンジ位置をコンクリート表面と 仮定した時の, H-30-350 の終局耐力時の変形状態と作用する力を示 す。アンカーボルトの変形には, 変位計から得られた終局耐力時の 鉛直変位 ${ }_{\text {max }} \delta_{V}$ と水平変位 ${ }_{\text {max }} \delta_{H}$ を用いた。図 $10(\mathrm{a})$ 上り, 塑性ヒンジ での回転角, つまりアンカーボルトの材軸の傾き $\phi 254$ 度と加力方 向 $\theta$ とは異なり，上記の仮定とは異なる結果となった。

そこで, 写真 2(a)に示すようにコンクリート内部でアンカーボル トの曲げ変形が見られ, また, 図 5 よりアンカーボルトにはコンク リート表面より深い位置で大きく曲げ歪度 $\varepsilon^{\mathrm{M}}$ が生じていることか ら, 図 10(b)に示すように塑性ヒンジの位置がコンクリートの内部に あると仮定する。コンクリート内部のアンカーボルトの変形状態に 関して弾性床上梁理論（以下, BEF）（図 11）を適用した研究がさ

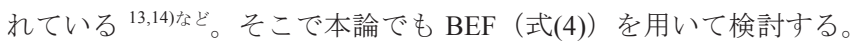
コンクリート内部の塑性ヒンジ位置はアンカーボルトの最大曲げモ ーメント深さ $l_{\text {max }}$ (式(5)) とした。ただし境界条件は, 半無限長梁, 梁始端にせん断力のみが作用し曲げモーメントは作用しないとした (式(a),(b),(c))。

$$
\begin{gathered}
E I \cdot\left(d^{4} y / d x^{4}\right)=-k^{\prime} d_{a} \cdot y \\
\left.y\right|_{x \rightarrow \infty}=0 \\
\left.M\right|_{x=0}=0 \\
\left.Q\right|_{x=0}=-{ }_{\text {max }} q_{e} \\
l_{\text {max }}=\pi / 4 \beta
\end{gathered}
$$

ここで, $E I$ はアンカーボルトの曲げ剛性 $\left[\mathrm{Nmm}^{2}\right], k^{\prime} d_{a}$ はコンクリー 卜反力係数 $\left[\mathrm{N} / \mathrm{mm}^{2}\right]$ である。また $\beta\left[\mathrm{mm}^{-1}\right]$ は $k^{\prime} d_{a}$ の関数であり, 式(6) で表わされる。

$$
\beta=\sqrt[4]{k^{\prime} d_{a} / 4 E I}
$$

コンクリート反力係数 $k^{\prime} d_{a}$ が定まれば $l_{\max }$ は決定される。コンクリ
一ト反力係数内の $k^{\prime}$ はコンクリート圧縮強度 $\sigma_{B}$ 等によって定まり, 本論では式(7) ${ }^{15)}$ を用いて定めた。

$$
k^{\prime}=269 \times \sqrt{\sigma_{B}} \times d_{a}{ }^{-2 / 3}
$$

BEF, 及び式(7)に基づくと, H-30-350 のアンカーボルトの最大曲 げモーメント深さ $l_{\max }$ は $22.6 \mathrm{~mm}$ となった。図 $10(\mathrm{~b})$ に $l_{\max }$ を用いた 変形状態を示すが, 実験での加力方向 $\theta$ が 30 度であったのに対し, 材軸の傾き $\phi$ は33度となり概ね一致した。B-30-350 も同様に塑性ヒ ンジの位置を BEF，及び式(7)を用いて検討したところ， $\theta$ と中は概ね 対応する結果となった。

BEF とコンクリート反力係数を適切に設定することで， $\theta$ が 30 度 の試験体では，せん断力に対してコンクリート表面に塑性ヒンジが 形成されるのではなく，コンクリート内で塑性ヒンジが形成される ことで加力方向 $\theta$ と材軸の傾き $\phi$ が近づき，アンカーボルト破断面に 対して垂直応力度が作用する抵抗機構を形成したと考えられる。

一方, 加力方向 $\theta$ が 60 度の試験体は, 図 $10(\mathrm{c})$ に示す BEF, 及び式 (7)に基づく検討より，加力方向 $\theta$ と材軸の傾き $\phi$ は対応しなかった。 終局耐力 $\max _{e} n_{e}$ が引張力を受ける時の破断耐力 $p_{a 1}$ より 2 割程度低く なっていることからも，アンカーボルト破断面に対して垂直応力度 とせん断応力度が作用していたと考えられる。

\section{2 付着破壊耐力}

図 12 に付着破壊に至った試験体の評価結果を示す。実験で得られ た終局耐力は計算值を 1.1 1.2 倍上回っており, 妥当に評価できて いる。また, 計算值で予測された破壊モードとも一致した。計算值 にへりあき距離 $c$ による低減を与えない場合, 終局耐力は計算值の 0.6 倍程度と危険側になることから, 低減の有効性が確認できた。

\section{3 コーン状破壊耐力}

図 13 にコーン状破壞に至った試験体の評価結果を示す。B-60-200 以外の試験体の終局耐力は計算値の $0.5 \sim 0.9$ 倍程度となり, 危険側 の評価となった。また, H-0-200 以外の試験体では計算值で予測さ

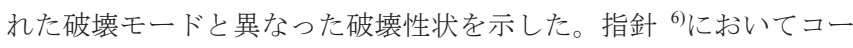
ン状破壊耐力の下限值は, 式(3)に安全係数 $2 / 3$ を乗じて式(8)で与え られるとしている。

$$
\left({ }_{\max } p_{e} / p_{a}\right)^{2}+\left({ }_{\max } q_{e} / q_{a}\right)^{2}=(2 / 3)^{2}
$$

図 13 に式(8)を併せて示すと, 下限值を下回る試験体もあり, 安 全係数を導入しても危険側の評価となっている。本実験の加力方法 は，せん断力によるアンカーボルトの加力点での回転に対する固定 度が小さくなっており，これが危険側の評価となった原因の一つと 考える。

図 14 に, 縦軸に終局耐力時の引張力 $\max _{e} p_{e}$ をコーン状破壊耐力 $p_{a 2}$ で除した值を, 横軸に同様に, $\max q_{e}$ をコーン状破壊耐力 $q_{a 3}$ で除し た值とした相関図を示す。引張力のみが作用する場合に比べて, 組 合せ荷重としてせん断力が作用することで, 引張力成分における計 算值に対する終局耐力が低下しており, その傾向はアンカーボルト の種類に関わらず確認できる。またこの傾向は，指針で示された式 (3), (8)よりも各加力成分の相互の影響が大きく, 相関は一次関数的 である。そこで, 組合せ荷重を受けるコーン状破壊耐力の評価式と して, 安全係数 $2 / 3$ は変えず, 各加力成分の相互影響を大きくした 式(9)を示す。各加力成分の累乗部分を一乗とし単純累加する一次式 で，各加力成分の相互影響を大きくした。

$$
\left({ }_{\max } p_{e} / p_{a 2}\right)+\left({ }_{\max } q_{e} / q_{a 3}\right)=2 / 3
$$


図 14 に式(9)を示すと, ばらつきはあるものの, 実験結果の中央 值を概初捉えている。図 13 には, 破壊性状に関わらず各加力成分の 累乗部分を一乗とした式(10)を示す。

$$
\left(\max p_{e} / p_{a}\right)+\left({ }_{\max } q_{e} / q_{a}\right)=2 / 3
$$

図 13 より, 式(10)はおおよそ下限值を捉えている。

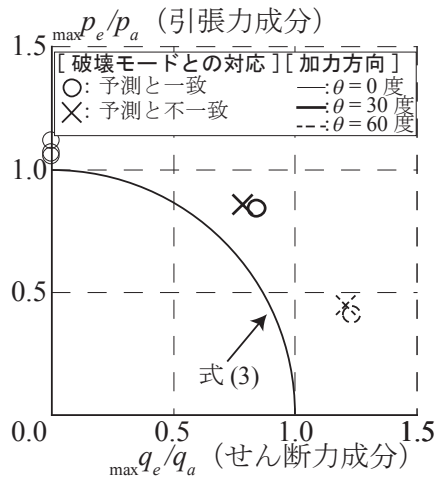

図 9 アンカーボルト

破断耐力評価

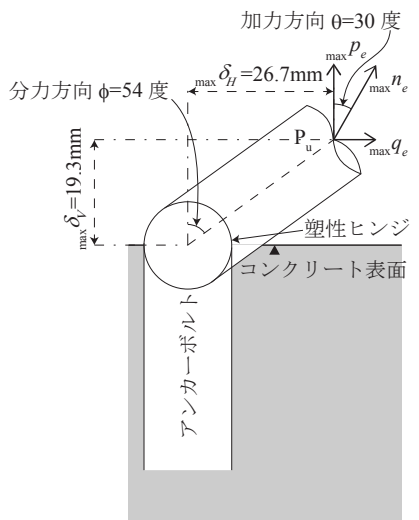

(a) 変位計による変形状態 $(\mathrm{H}-30-350)$

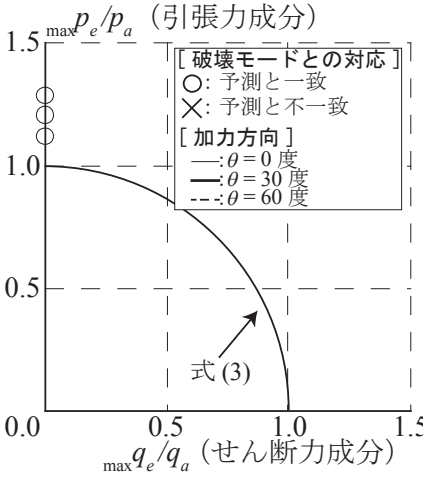

図 12 付着破壊耐力評価

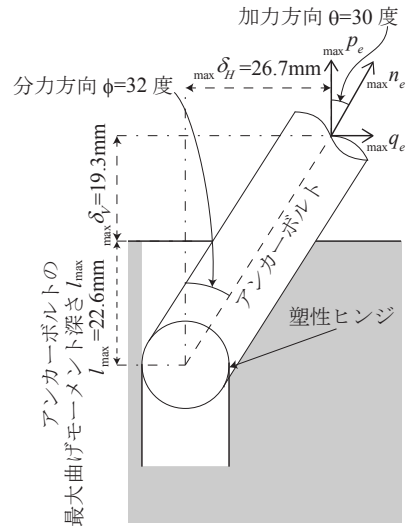

(b) BEF を用いた変形状態 $(\mathrm{H}-30-350)$

\section{5. 荷重 - 変位関係と降伏耐力評価}

図 15 に荷重 - 変位関係の一例を, 縦軸の荷重に $\mathrm{PC}$ 鋼棒の軸力 $n_{e}$ を加力方向 $\theta$ に応じて分解した引張力 $p_{e}$ とせん断力 $q_{e}$ を, 横軸の変 位にアンカーボルトの鉛直变位 $\delta_{V}$ と水平変位 $\delta_{H}$ をそれぞれ示寸。図 中には同様に, 終局耐力 $\max _{e}$ と $\mathrm{H}$ ボルトに貼付した歪ゲージの計測 值が降伏歪度に達した時の $\mathrm{PC}$ 鋼棒の軸力 $n_{e y}$ を $\theta$ に応じて分解した
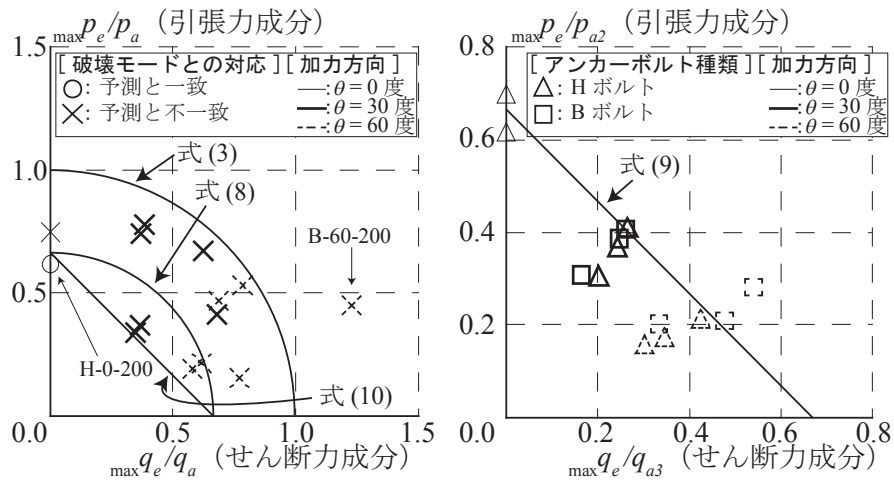

図 13 コーン状破壊耐力評価

コーン状破壊耐カにおける
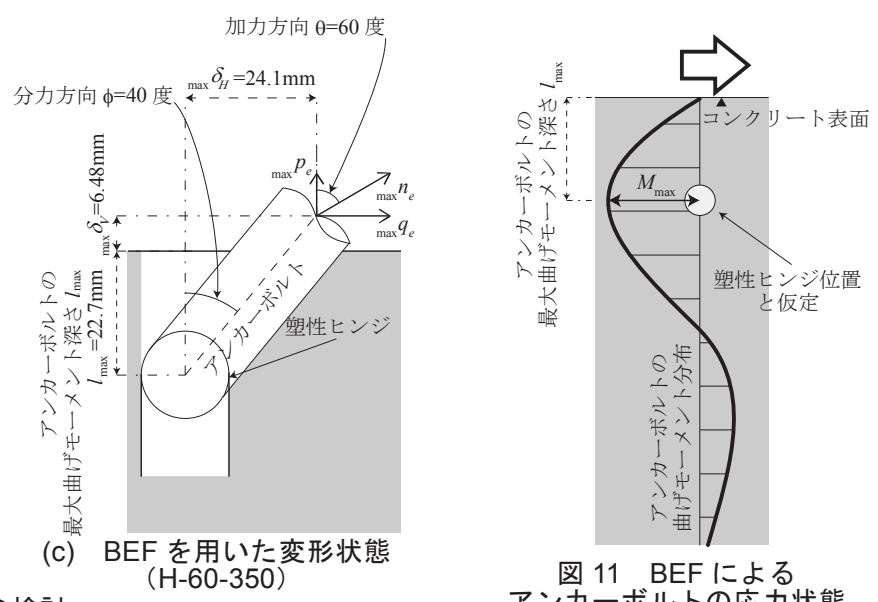

図 11 BEFによる

アンカーボルトの応力状態
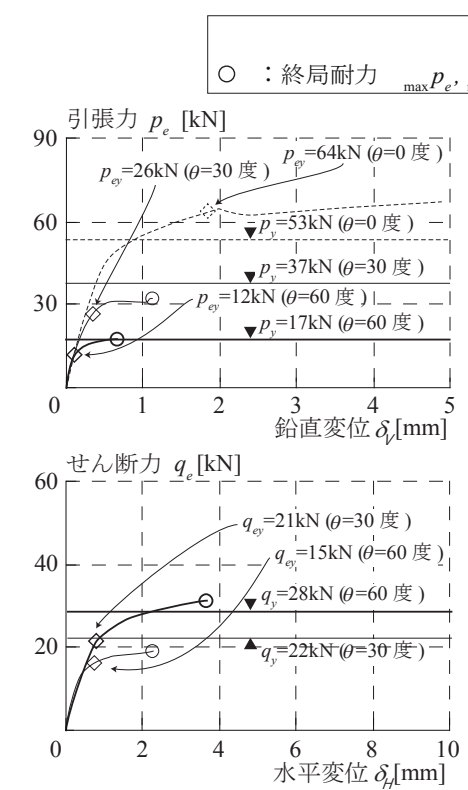

(a) $\mathrm{H}$ ボルト $c=75$ 配筋有 
$\max p_{e}, \quad \max q_{e}$ と $p_{e y}, q_{e y}$ を示す。ただしここに示す図は, 載荷開始初 期に計測が乱れたデータを削除し, 各試験体で原点が重なるように 横軸をシフトしている。

前述の歪度性状において, 配筋の有無によりアンカーボルトの曲 げ歪度 $\varepsilon^{\mathrm{M}}$ が $1 / 3$ 程度低下したことを述べた（図 6(b)）。しかし, 荷重 一変位関係の剛性では有意差が見られなかった。

各実験における剛性低下について, 剛性低下の要因の一つである アンカーボルトの降伏を von Mises の降伏条件を用いて検討寸る。 図 16 に示寸ように, $\mathrm{PC}$ 鋼棒の軸力 $n_{e}$ を加力方向 $\theta$ に応じて分解し た引張力 $p_{e}$ とせん断力 $q_{e}$ をアンカーボルトの軸部断面積, またはね じ部有効断面積のうち小さい断面積 $a$ で除して得た垂直応力度 $\sigma$, 及びせん断応力度 $\tau$ と von Mises の降伏条件を仮定する。これらの仮 定より von Mises の降伏条件に基づく降伏耐力 $p_{y}, q_{y}$ を求めた。

図 15 に von Mises の降伏条件に基づく降伏耐力 $p_{y}, q_{y}$ を併せて示 す。加力方向 $\theta$ が 0 度の試験体の剛性低下した荷重は, von Mises $の$ 降伏耐力 $p_{y}$ と概衫対応し, $\mathrm{H}$ ボルトの試験体において歪度が降伏歪
度に達した荷重 $p_{e y}$ より 1 割程度低くなっていた。これより, 剛性低 下はアンカーボルトのコンクリートから突出したナット下ねじ部が 降伏することで生じており, von Mises の降伏条件により評価できた。 一方, H-0-200 の剛性低下は $\mathrm{PC}$ 鋼棒の軸力 $n_{e}$ が $40 \mathrm{kN}$ 程度で生じて おり,これは $p_{y}(262 \mathrm{kN})$ の 2 割程度であった。H-0-75 でも $p_{y}$ の 5 割 程度で剛性低下が生じた。図 5 に示した歪度性状よりアンカーボル 卜頭部での支圧により抵抗していたことは明らかであり，剛性低下 は頭部での支圧破壊による影響 ${ }^{16)}$ と考える。コンクリートの支圧破 壊による剛性の変化はアンカーボルトの降伏による剛性低下に比べ 緩やかな傾向を示した。

加力方向 $\theta$ が 30 度と 60 度の試験体では, 剛性低下した荷重はvon Mises の降伏条件に基づく降伏耐力 $p_{y}, q_{y}$ よりも 3 割程度低くなっ ていた。一方 H ボルトでへりあき距離 $c$ が 200 以外の試験体では, 歪度が降伏歪度に達した荷重 $p_{e y}, q_{e y}$ と対応した。歪度性状より曲 げ降伏していたことから, 剛性低下はアンカーボルトの軸部が曲げ 降伏することで生じ, von Mises の降伏条件では剛性低下した荷重を

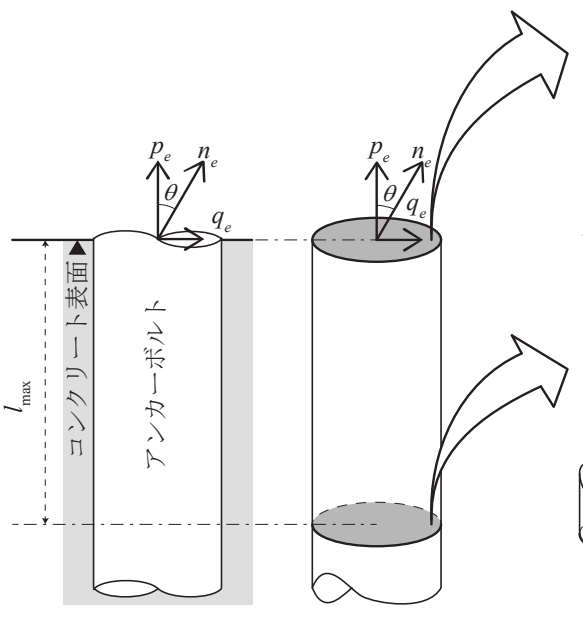

von Mises の降伏条件に基づく降伏耐力
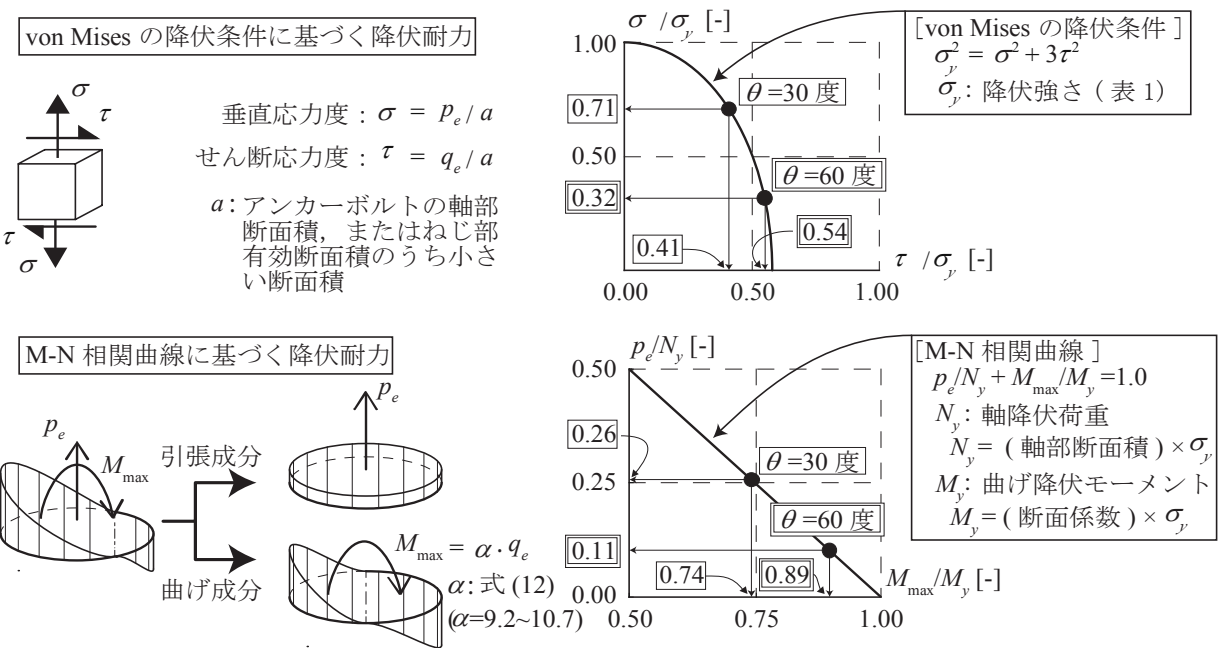

図 16 アンカーボルトの降伏耐カ von Mises の降伏条件と降伏時の M- $\mathrm{N}$ 相関曲線に基づいて

[ 加力方向 ] - - - : $: \theta=0$ 度 — $: \theta=30$ 度 $-: \theta=60$ 度

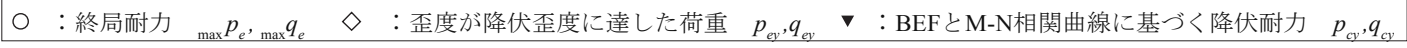
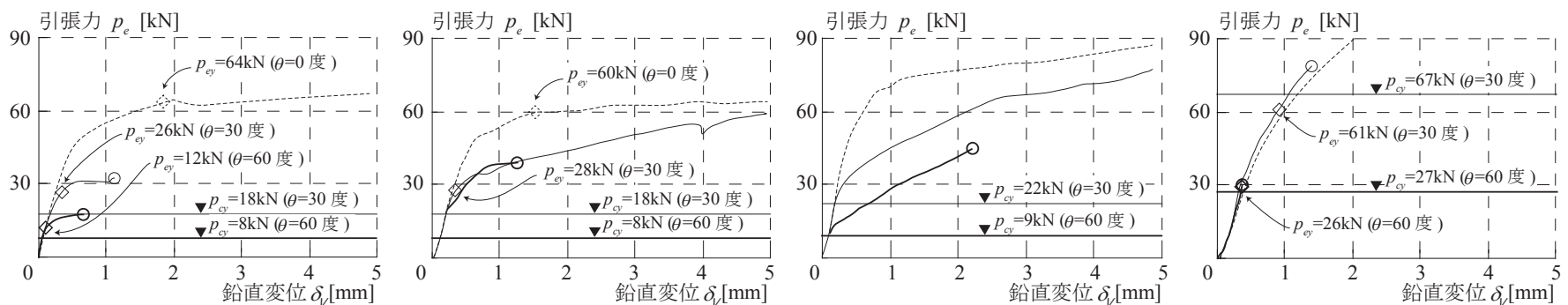

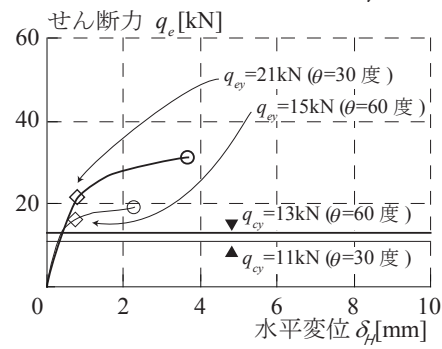

(a) $\mathrm{H}$ ボルト $c=75$ 配筋有

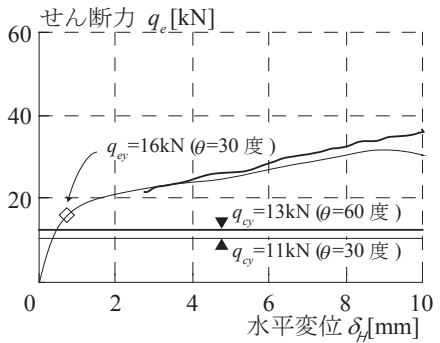

(b) $\mathrm{H}$ ボルト $c=350$

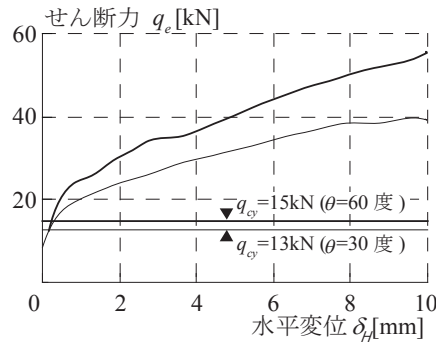

(c) B ボルト $c=350$

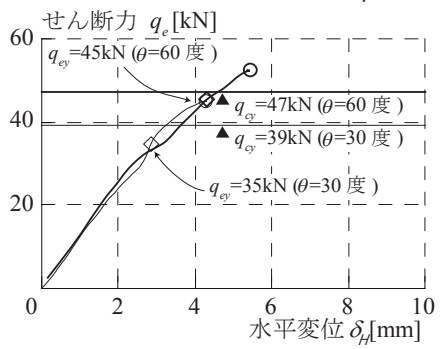

(d) $\mathrm{H}$ ボルト $c=200$

図 17 荷重 - 変位関係と BEF の曲げ降伏耐力 
過大評価することがわかった。 H ボルトで $c$ が 200 のアンカーボル トに高強度鋼を用いた試験体では上記と異なり $p_{e y}, q_{e y}$ と対応しな かった。これは, アンカーボルトに高強度鋼を用いることで, アン カーボルトに先行してコンクリートが破壊したためと考えられる。

荷重 - 変位関係における主な剛性低下は, 本実験の範囲ではアン カーボルトの降伏によって生じた。アンカーボルトが降伏するとき の荷重は加力方向 $\theta$ が 0 度では von Mises の降伏条件による降伏耐力 で評価できたが， $\theta$ 要 30 度，60 度では過大評価する結果となった。 これは, アンカーボルトの軸部で曲げ降伏が生じているためである。 そこで，アンカーボルト軸部での曲げ降伏を BEF と M-N 相関曲 線を用いて検討する。図 16 に示すアンカーボルト降伏時の M-N 相 関曲線, 及びアンカーボルトの曲げ降伏は式(4)に示す BEF より, 最 大曲げモーメント梁さ $l_{\max }$ の位置で生じると仮定する。アンカーボ ルトが引張力と曲げモーメントによる降伏する時の M-N 相関曲線 は, アンカーボルト軸方向の引張力 $p_{e}$ を引張力降伏耐力 $N_{y}$ で除し た值と, $l_{\max }$ の位置の曲げモーメント $M_{\max }$ を曲げ降伏耐力 $M_{y}$ で除し た值の関係で示される。また, $M_{\max }$ とせん断力 $q_{e}$ の関係は, 式(4), 及び式(a-c)から式(11)で示される。

$$
M_{\text {max }}=\alpha \cdot q_{e}
$$

ここで $\alpha$ は式(12)で表わされる定数である。

$$
\alpha=\left(e^{-\pi / 4} \cdot \sin \pi / 4\right) / \beta
$$

これらの仮定より BEF と M-N 相関曲線に基づく降伏耐力 $p_{c y}, q_{c y}$ を求めた。 $\mathrm{M}-\mathrm{N}$ 相関曲線に基づく引張力 $p_{e}$ による曲げ降伏モーメン ト $M_{y}$ の低減は, 本実験の範囲において $M_{y}$ に対する比で, 加力方向 $\theta$ が 30 度で $0.74,60$ 度で 0.89 であった。

図 17 に荷重 - 変位関係と併せて BEF と M-N 相関曲線に基づく降 伏耐力 $p_{c y}, q_{c y}$ を示す。 $p_{c y}, q_{c y}$ は, アンカーボルトに高強度鋼を用 いた $\mathrm{H}$ ボルトでへりあき距離 $c$ が 200 以外の試験体 (図 17(a),(b),(c)) において, 歪度が降伏歪度に達した荷重 $p_{e y}, q_{e y}$ を安全側に評価し, 実験での荷重 $p_{e y}, q_{e y}$ は計算での耐力 $p_{c y}, q_{c y}$ を 1.5 倍程度上回って いた。一方，H ボルトでへりあき距離 $c$ が 200 の試験体（図 17(d)） では， $p_{c y}, q_{c y}$ と $p_{e y}, q_{e y}$ は良く対応した。

以上より, 組合せ荷重下でのアンカーボルト軸部での曲げ降伏時 の耐力は, BEF と M-N 相関曲線を仮定することで安全側に評価で き，軸力の影響を考慮しない場合は危険側の評価になる。

\section{6. まとめ}

コンクリート内に設置した頭付きアンカーボルトと接着系アンカ 一ボルトを対象に, アンカーボルト材軸方向に対して 0 度, 30 度, 60 度方向に引張力を与えることでアンカーボルトに引張応力度, せ 几断応力度, 及び曲げ応力度を作用させる実験を行なった。実験結 果に基づき, 組合せ荷重を受けるアンカーボルトとその周辺コンク リートの力学的挙動に関する検討を行い, 以下の結論を得た。

1) アンカーボルト破断, 及び付着割裂破壊に至った試験体では, 実 験で得られた終局耐力が指針式 ${ }^{6}$ による計算值を上回る安全側の 評価となった。一方, コーン状破壞に至った試験体では, 実験で 得られた終局耐力が指針式 (9よよ下限值を下回るものもあり， 危険側の評価となった。また指針式 ${ }^{6}$ により予測される破壊モー ドと不一致の試験体が多く, コーン状破壊の計算值を過大に評価 する傾向がみられた。この原因の一つとして, アンカーボルトの
曲げに対する固定度が小さいことが考えられる。

2) アンカーボルト破断により決まる終局耐力は, アンカーボルトに 作用するせん断力によるコンクリート内での変形状態を弾性床上 梁理論により評価することで, 指針式 ${ }^{6)}$ と比べて終局耐力評価の 精度を向上することができた。

3) コーン状破壊による終局耐力は, せん断力が作用することで引張 力における計算值に対する終局耐力が低下し，その傾向は直線的 であった。引張力成分とせん断力成分の関係を一次関数で評価す ることで，実験結果の中央值を捉えることができた。

4) アンカーボルトの荷重と変位の関係における剛性低下は, アンカ 一ボルトの降伏時に生じた。

5) 組合せ荷重下でのアンカーボルトの降伏荷重は, von Mises の降 伏条件に基づくと危険側の評価となった。一方，弾性床上梁理論 と降伏時の M-N 相関曲線に基づき評価をすると, 降伏荷重を安全 側に評価することができた。この時，引張力による低減を適切に 設定する必要がある。

\section{参考文献}

1) 阿部保彦，宇佐美滋，松崎育弘：先付けアンカーの引張耐力に及ぼすフ ック及びヘッドの形状・寸法の影響, 日本建築学会大会学術講演梗概集, pp.1905-1906, 1983.09

2) 清原俊彦, 松崎育弘, 中野克彦, 福本晃治 : 接着系あと施工アンカーの 構造特性に関する実験研究，コンクリート工学年次論文報告集，Vol.20， No.3, pp.199-204, 1998

3) 浅田勇人, 吉敷祥一, 山田哲 : 鉄骨造露出型柱脚における鉄筋コンクリ 一ト基礎・アンカー系の側方破壊挙動, 日本建築学会構造系論文集, Vol.75, No.654, pp.1517-1525, 2010.08

4) 松崎育弘, 阿部保彦, 宇佐美滋 : 樹脂アンカーのせん断耐力(正負交番繰 返しせん断力および組合せ力)に関する実験研究，関東支部研究報告集， No.64, pp.253-256, 1981

5) Y. Li, R. EligeHAUSEN, J. OZBOLT, B. LEHR : Numerical Analysis of Quadruple Fastenings with Bonded Anchors, ACI Structural Journal, Vol.99, No.2, pp.149-156, 2002.03-04

6) 日本建築学会 : 各種合成構造設計指針・同解説，2010.11

7) 大橋芳郎, 中島茂寿 : 引張力・せん断力・組み合わせ応力を受けるアン カーボルト露出部の力学的性状に関する実験的研究, 日本建築学会大会学 術講演梗概集, C-1, 構造 III, pp.391-392, 1996.09

8) 中島茂壽 : 繰り返しの組合せ引張・せん断力を受けるアンカーボルト露 出部の力学性状（M16 の場合），日本建築学会大会学術講演梗概集，C-1, 構造 III, pp.741-742, 2000.09

9) Patrik, J. M., G. S. Roger, W. F. John : Headed Steel Anchor under Combined Loading, AISC Engineering Journal, Vol.10, pp.43-52, Second Quarter/1973 10）山田哲，松本由香，伊山潤，五十子幸樹，吉敷祥一，池永昌容，島田侑 子, 小山毅, 見波進, 浅田勇人: 東北地方太平洋沖地震等で被災した鉄骨 造文教施設の調査一調査の概要一, 日本建築学会技術報告集, Vol.18, No.40, pp.935-940, 2012.10

11) 吉敷祥一, 山田哲, 松本由香, 浅田勇人, 小山毅, 島田侑子 : 東北地方 太平洋沖地震等による鉄骨造文教施設の柱脚 - 定着部被害, 日本建築学会 技術報告集，Vol.19，No.42，pp.585-590，2013.06

12) 山田哲, 伊山潤, 島田侑子, 松本由香, 長谷川隆, 清家剛, 中野達也, 吉敷祥一: 東北地方太平洋沖地震および余震による学校体育館の構造被害, 日本建築学会技術報告集，Vol.20，No.44，pp.133-138，2014.02

13) 中野克彦, 松崎育弘：プレキャスト RC 部材接合面におけるせん断抵抗 要素の耐力累加方法, 日本建築学会構造系論文集, No.550, pp.151-158, 2001.12

14) 阿野田瑛二, 片平直也, 高橋之, 市之瀬敏勝 : 鉄筋コンクリート部材内 にあるダウエル鉄筋の荷重変形関係, コンクリート工学年次論文集, Vol.35, No.2, pp.73-78, 2013

15) Dei PoliS., P. M. Di, P. G. Gambarova : Shear Response, Deformations, and Subgrade Stiffness of a Dowel Bar Embedded in Concrete, ACI Structural Journal, Vol.89, No.6, pp.665-675, 1992.11-12

16) 近藤吾郎，森田司郎：引抜き力をうけるアンカーボルトの応力伝達機構 の解析, 日本建築学会構造系論文報告集, No.435, pp.141-150, 1992.05 


\title{
EXPELIMENTAL STUDY ON MECHANICAL BEHAVIOR OF ANCHOR BOLTS AND SURROUNDING CONCRETE UNDER COMBINED LOADING
}

\author{
Yuki SHIRAI ${ }^{* 1}$, Satoshi YAMADA *2, Hiroyasu SAKATA *3, \\ Yuko SHIMADA*4 and Shoichi KISHIKI ${ }^{* 5}$ \\ ${ }^{* 1}$ Grad. Stud., Tokyo Institute of Technology, M. Eng. \\ JSPS Research Fellow \\ ${ }^{*} 2$ Prof., S.E.R.C., Tokyo Institute of Technology, Dr. Eng. \\ ${ }^{* 3}$ Prof., Graduate School of Science and Eng., Tokyo Institute of Technology, Dr. Eng. \\ ${ }^{*}$ Assoc. Prof., Graduate School of Engineering, Chiba Univ., Dr. Eng. \\ ${ }^{* 5}$ Assoc. Prof., S.E.R.C., Tokyo Institute of Technology, Dr. Eng.
}

Both headed and bonded anchor bolts are used for installing not only simple equipment and facilities, but also massive structural elements such as newly-built frames for retrofit and dampers. Many studies including pure shear tests, pulled out tests and numerical analyses have been carried out all over the world. According to previous studies, the concept of ultimate strength is incorporated by design recommendations for composite construction. However, there are few study on concrete core failure under combined shear and tension. During the 2011 Tohoku earthquake, the concrete failure instead of bolt fracture was observed at connections, probably it occurred by combined loads. The purpose of this study is to describe the failure behavior, ultimate strength, yield strength of anchor bolts and the surrounding concrete under combined loads and the effect of reinforcement in the concrete.

24 specimens were prepared, each of which consisted of one anchor bolt and the surrounding concrete. The anchor bolts in the specimens were subjected to monotonic loading in an inclined direction. Monotonic loading test were conducted for both headed and bonded anchor bolts in ordinary concrete. In the experiment, five parameters, that is, the specified concrete strength, the types of anchor bolts, the loading directions, the distance to the concrete edge and the existence of reinforcement, were considered. The load and displacement of the anchor bolts, the strain of the reinforcement and the crack widths were measured.

Three types of failure were observed, that is, the fractures of the anchor bolts, the bond slip failure and the concrete cone failure.

The following findings were obtained from the experiment.

(1) The ultimate strengths when the anchor bolt ruptures or the bond fractures under combined loading are in good correlations with the design recommendation. However, the ultimate strengths when the concrete cone failure occurs are in bad correlations with the design recommendation. New equations are proposed for evaluating the ultimate strengths under combined loads and evaluate the experimental test results better than the design recommendation.

(2) Stiffness deterioration occurs when the anchor bolts yield. The yield strength under combined loads is in good correlations with the estimates based on a beam on an elastic foundation theory and the M-N interaction curve. 